\title{
Dampak Sosial Dan Ekonomi Pasca Gempa Bumi Di Kecamatan Pemenang
}

\author{
Nurdin \\ UT UPBJJ Mataram \\ Email: nurdin@ut.ac.id
}

\begin{abstract}
Abstrak
Negara Indonesia merupakan negara yang paling banyak gunung api aktifnya. Hal ini disebabkan pertemuan lempeng tektonik dunia, yaitu lempeng Indo-Australia, Eurasia, serta Pasifik. Masalah meliputi seberapa besar dampak gempa bumi terhadap pendapatan masyarakat sebelum dan sesudah gempa, dan seberapa besar dampak gempa bumi terhadap kehidupan sosial masyarakat sebelum dan sesudah gempa. Penelitian meliputi menganalisis dampak gempa bumi terhadap pendapatan masyarakat sebelum dan sesudah gempa, dan menganalisis dampak gempa bumi terhadap kehidupan sosial masyarakat sebelum dan sesudah gempa. Manfaat penelitian meliputi mengetahui seberapa dampak gempa bumi terhadap pendapatan masyarakat sebelum dan sesudah gempa, dan mengetahui seberapa besar dampak gempa bumi terhadap kehidupan sosial masyarakat sebelum dan sesudah gempa. Metode yang digunakan dalam penelitian ini adalah metode deskriptif, yaitu metode yang bertujuan untuk meneliti status sekelompok manusia, suatu objek, suatu kondisi, sistem pemikiran ataupun suatu kejadian peristiwa masa sekarang yang bertujuan untuk membuat deskripsi, gambaran atau lukisan secara sistematis, faktual dan aktual mengenai fakta, sifat serta hubungan antara fenomena yang diselidiki (Nazir,2009). Daerah penelitian akan dilaksanakan di Kecamatan Pemenang. Teknik pengambilan sampel secara Purposive Sampling. Data secara umum, struktur penduduk Kabupaten Lombok Utara pada tahun 2017 didominasi oleh penduduk dengan jenis kelamin perempuan. Responden sebagian besar berumur 26 - 45 tahun sebanyak 96 orang (52,7\%). Hal ini menunjukkan bahwa dari segi umur penduduk Kecamatan Pemenang berada pada usia produktif. Penduduk tamat SD sebanyak 64 orang $(35,2 \%)$. Tidak sekolah sebanyak 31 orang (17,0\%). Tidak tamat SD sebanyak 18 orang $(9,9 \%)$. Kondisi ini menunjukkan bahwa target pendidikan wajib belajar 9 tahun masih belum tercapai. Pekerjaan utama responden adalah wiraswasta sebanyak 69 orang (37,9\%) dan buruh/tukang bangunan sebanyak 53 orang $(29,1 \%)$. Wajib belajar 9 tahun responden masih belum tercapai. Hal ini dapat dipahami jika dilihat dari tingkat pendidikan responden yang sebagian besar tidak sekolah dan tidak tamat. Penduduk Kecamatan Pemenang wajib belajar 9 tahun belum tercapai. Tingkat pendidikan yang masih rendah berdampak pada profesi pekerjaan. Gempa bumi meninggalkan dampak buruk pada kehidupan masyarakat disegala bidang, dampak tersebut baru bisa normal kembali membutuhkan waktu yang lama, karena secara tidak langsung berhubungan dengan tingkat pendidikan masyarakat yang masih rendah.
\end{abstract}

Kata Kunci: Sosial Dan Ekonomi Pasca Gempa Bumi 


\section{PENDAHULUAN}

\section{Latar Belakang}

Indonesia merupakan negara kepulauan terbesar di dunia yang terletak di antara Benua Asia dan Benua Australia serta Samudera Hindia dan Samudra Pasifik. Meskipun menyimpan keindahan alam yang sangat luar biasa, bangsa Indonesia juga menyadari bahwa wilayah nusantara ini memiliki kurang lebih 129 gunung api aktif, dan berada pada pertemuan tiga lempeng tektonik aktif dunia yaitu lempeng IndoAustralia, Eurasia, serta Pasifik. Undangundang Nomor 24 Tahun 2007 Tentang Penanggulangan Bencana menyatakan bahwa bencana merupakan peristiwa atau serangkaian peristiwa yang mengancam dan mengganggu kehidupan penghidupan masyarakat yang disebabkan baik oleh faktor alam dan faktor non alam, maupun faktor manusia sehingga mengakibatkan timbulnya korban jiwa, kerusakan lingkungan, kerugian harta benda, dan dampak psikologis.

Pada umumnya bencana alam terjadi karena adanya perubahan pada kondisi alam. Gempa bumi terjadi di sepanjang jalur-jalur pertemuan lempeng tektonik di darat atau lantai samudera. Contoh bencana alam geologi yang paling umum adalah gempa bumi. Gempa bumi terjadi karena gerakan lempeng tektonik. Gempa bumi pada lantai samudera dapat memicu gelombang tsunami ke pesisir-pesisir yang jauh.

Dari peristiwa gempa yang telah terjadi di Lombok terutama daerah Kabupaten Lombok Utara menyebabkan daerah pedesaan mengalami beberapa kerugian khusus pada aspek sosial ekonomi. Secara wilayah, kerusakan dan kerugian akibat gempa di NTB paling banyak adalah di Kabupaten Lombok Utara yang mencapai lebih dari 2,7 trilyun (BNPB, 2018). Berdasarkan uraian di atas, maka peneliti tertarik untuk mengambil judul: "Dampak Sosial dan Ekonomi Pasca Gempa Bumi di Kecamatan Pemenang”.

\section{Rumusan Masalah}

1. Seberapa besar dampak gempa bumi terhadap pendapatan masyarakat sebelum dan sesudah gempa
2. Seberapa besar dampak gempa bumi terhadap kehidupan sosial masyarakat sebelum dan sesudah gempa

\section{Tujuan Penelitian}

1. Menganalisis dampak gempa bumi terhadap pendapatan masyarakat sebelum dan sesudah gempa

2. Menganalisis dampak gempa bumi terhadap kehidupan sosial masyarakat sebelum dan sesudah gempa

\section{Manfaat Penelitian}

1. Mengetahui seberapa dampak gempa bumi terhadap pendapatan masyarakat sebelum dan sesudah gempa

2. Mengetahui seberapa besar dampak gempa bumi terhadap kehidupan sosial masyarakat sebelum dan sesudah gempa

\section{KAJIAN PUSTAKA \\ Gempa Bumi}

Gempa bumi adalah peristiwa bergetarnya bumi akibat pelepasan energi di dalam bumi secara tiba-tiba yang ditandai dengan patahnya lapisan batuan pada kerak bumi. Akumulasi energi penyebab terjadinya gempa bumi dihasilkan dari pergerakan lempeng-lempeng tektonik. Energi yang dihasilkan dipancarkan kesegala arah berupa gelombang gempa bumi sehingga efeknya dapat dirasakan sampai ke permukaan bumi (BMKG).

\section{Dampak Bencana}

European Commission for Latin America and Caribbean (ECLAC) mengusulkan sebuah metodologi yang dirancang untuk melakukan penilaian dampak bencana bagi ekonomi (Zapata-Marti,1997), yang dibedakan dalam tiga kelompok:

1. Direct damages (kerusakan langsung), meliputi semua kerusakan pada aset tetap, modal dan persediaan barang jadi dan setengah jadi, bahan baku dan suku cadang yang terjadi secara bersamaan sebagai konsekuensi langsung. Pada tahap ini akan menyangkut pengeluaran untuk bantuan darurat.

2. Indirect damages (kerusakan tidak langsung), dampaknya lebih pada arus barang yang tidak akan diproduksi dan 
jasa yang tidak akan diberikan setelah bencana. Kerusakan tidak langsung ini dapat meningkatkan pengeluaran operasional karena rusaknya infrastruktur. Biaya yang bertambah terletak pada penyediaan layanan alternatif (alternatif cara produksi, distribusi dan penyediaan barang dan jasa).

3. Secondary effect (dampak sekunder), meliputi dampak pada kinerja ekonomi secara keseluruhan yang diukur melalui variabel ekonomi makro yang paling signifikan. Variabel yang relevan dapat Produk Domestik Bruto (PDB) yang mencakup keseluruhan dan sektoral, neraca perdagangan dan neraca pembayaran, tingkat utang dan cadangan moneter, keadaan keuangan publik dan investasi modal bruto. Pada sisi keuangan publik seperti penurunan pendapatan pajak atau peningkatan pengeluaran dapat menjadi sangat penting.

\section{Dampak makro ekonomi}

Dampak makroekonomi merupakan dampak sekunder dari bencana. Bencana selalu berdampak buruk dalam pengamatan ekonomi makro jangka pendek berkaitan dengan menurunnya produksi. Dinegaranegara berkembang, penurunan output lebih besar setelah bencana jauh lebih besar dibandingkan dengan negaramaju (Noy,2007).

Penelitian dari biaya output
makroekonomi
mengungkapkan beberapa pola yang menarik. Hasilnya menunjukkan bahwa dinegaranegara dengan tingkat melek huruf yang lebih tinggi, institusi yang lebih baik, pendapatan perkapita lebih tinggi, keterbukaan perdagangan lebih tinggi, dan tingkat pengeluaran pemerintah yang lebih tinggi akan lebih mampu menahan kejutan bencana awal dan mencegah penularannya ke ekonomi makro. Ini semua menunjukkan bahwa kemampuan untuk memobilisasi sumberdaya untuk rekonstruksi yang lebih tinggi. Kondisi keuangan juga tampaknya menjadi penting, negara-negara dengan cadangah devisa lebih tinggi dan tingkat kredit domestik yang lebih tinggi akan lebih kuat dan lebihmampu bertahan dari akibat bencana secara ekonomi dan tidak banyak mempengaruhi produksi domestik.

Dampak makro ekonomi adalah setiap perubahan variabel ekonomi utama yang disebabkan oleh dampak langsung dan tidak langsung dari bencana yang menggambarkan perubahan kegiatan ekonomi. Dampak yang. paling penting adalah Produk Domesti Bruto (PDB), investasi, neraca pembayaran dan keuangan publik. Tergantung pada jenis dan skala bencana, maka estimasi dampak pada inflasi dan lapangan kerja juga cukup relevan. Kuantifikasi dampak ekonomi makro biasanya dilakukan bagi perekonomian nasional secara makro, meskipun pada prinsipnya apabila informasi tersedia memungkinkan dilakukan pada skala yang lebih kecil. Mengestimasi dampak makroekonomi merupakan cara komplementer untuk melakukan penilaian dampak langsung dan tidak langsung. Karena variabel-variabel ekonomi makro yang dinamis dan terus berkembang, maka diperlukan membandingkan varuabel ekonomi makro setelah bencana terjadi dan jika bencana tidak terjadi.

Latar belakang informasi indikatorindikator ekonomi makro yang berkembang pada kondisi tanpa bencana dapat membantu untuk melakukan estimasi sebagai baseline untuk memastikan sejauh mana bencana mengganggu ekonomi makro pada tingkat yang dicapai. Estimasi yang dilakukan berdasar pada kemungkinan skenario yang berbeda, kerangka waktu utuk memperkirakan dampak ekonomi makro disesuaikan dengan skala bencana bahkan pada bencana skala besar bisa dilakukan untuk lima tahun setelah bencana. Penilaian ekonomi makro dimulai dengan mengumpulkan informasi mengenai tren ekonomi pra bencana dan fitur kebijakan ekonominya. Sumbernya bisa Bank sentral, kementerian ekonomi, pajak, keuangan dan perencanaan, badan statistik, universitas, 
organisasi regional dan internasional yang dikompilasi menjadi set data yang informatif bagi pembuatan kebijakan. Kelengkapan bisa ditambahkan dri data wawancara dan survei.

Proyeksi memungkinkan untuk menyiapkan bagaimana pertumbuhan ekonomi (PDB) diestimasi untuk melakukan pengembangan dari kondisi sebelum bencana dan juga tercermin dalam inflasi, ekspor, impor,dll. Estimasi dampak bencana terhdap PDB pun harus dilakukan secara riil. Bencana memiliki potensi inflasi melalui kapasitas ekonomi pasar, berupa produksi, distribusi, pemasaran dan konsumsi, namun inflasi sering hanya merupakan dampak sementara. Pada negara dengan perekonomian terbuka, permintaan yang meningkat pada bahan bangunan, makanan, energi dan air yang meningkat, kerusakan infrastruktur (pertanian atau industri) yang menyebabkan produksi domestik turun, transportasi, pemasaran dan komunikasi yang terganggu akan mengurangi kemampuan barang beredar, ada kekurangan dalam pasokan barang impor karena kelangkaan modal atau kerusakan transportasi, ada tingkat permintaan tenaga kerja terampil akan memaksa upah dan harga meningkat, dan kenaikan harga pangan dan komoditas lokal. Misalnya jika dalam satu bencana kekeringan pemerintah tidak menyediakan bahan pangan yang cukup, maka akan menekan ketersediaan pangan dan inflasi (Dréze dan Sen, 1989).

\section{Kondisi sosial}

Menurut Dalyono ( 2005 ) dalam Basrowi dan Juariyah ( 2010 ) Kondisi Soial adalah semua orang atau manusia lain yang mempengaruhi kita. Kondisi sosial yang mempengaruhi individu melalui dua cara yaitu langsung dan tidak langsung. Secara langsung yaitu seperti dalam pergaulan sehari - hari baik dari keluarga, teman dan pekerjaan. Secara tidak langsung melalui media masa baik cetak, audio maupun audio visual. Selanjutnya juga dijelaskan lingkungan sosial yang sangat berpengaruh pada proses dan hasil pendidikan adalah teman bergaul, lingkungan tetangga dan aktivitas dalam masyarakat. Linton (2000) dalam Basrowi dan Juariyah (2010) mengatakan kondisi sosial masyarakat mempunyai lima indikator yaitu : umur dan jenis kelamin, pekerjaan, prestise, family atau kelompok rumah tangga,dan keanggotaan dalam kelompok perserikatan. Dari kelima indikator tersebut, hanya indikator umur dan kelamin yang tidak terpengaruh oleh proses pendidikan, sehingga hanya empat indikator yang perlu diukur tingkat perbaikannya, guna mengetahui tingginya manfaat sosial bagi masyarakat. Menurut Ihsan (2003) dalam Basrowi dan Juariyah (2010) kondisi masyarakat di mana memiliki latar belakang pendidikan yang cukup, terdapat lembaga lembaga pendidikan dan sumber belajar didalamnya akan memberikan pengaruh positif terhadap semangat dan perkembangan belajar generasi muda.

Dalam hal ini di mana kondisi sosial ini berpengaruh secara negatif terhadap pendidikan, maka kondisi ini menjadi pembatas pendidikan. Orang tua sebagai pendidik secara kodrati harus mampu mengantisipasi pengaruh yang ada karena tidak semua pengaruh kondisi sosial merupakan pengaruh yang baik. Hal ini berarti bahwa lingkungan sosial juga mempengaruhi pencapaian pendidikan anak. Kondisi sosial masyarakat mempengaruhi proses dan hasil pendidikan.

\section{Dampak Gempa Tektonik Terhadap Kerusakan Fisik}

Menurut Endhiq Anang Pamungkas, kerusakan bangunan terbagi menjadi tiga kategori, yaitu roboh, rusak berat, dan rusak sedang atau ringan (lihat tabel).

Tabel 1. Kriteria Kerusakan Bangunan

\begin{tabular}{|c|c|c|c|}
\hline No & $\begin{array}{c}\text { Kategori } \\
\text { Kerusakan }\end{array}$ & Kriteria Kerusakan & Urian \\
\hline 1. & Roboh & $\begin{array}{l}\text { Bangunan roboh atau } \\
\text { sebagian besar } \\
\text { komponen struktur rusak }\end{array}$ & $\begin{array}{l}\text { Bangunan roboh total; } \\
\text { Atap runtuh; } \\
\text { Sebagian besar } \\
\text { kolom, balok, } \\
\text { dan/atau atap rusak; } \\
\text { Sebagian besar } \\
\text { dinding dan langit- } \\
\text { langit roboh; Instalasi } \\
\text { listrik rusak total; dan } \\
\text { Pintu/jendela } \\
\text { rusak total. }\end{array}$ \\
\hline
\end{tabular}




\begin{tabular}{|c|c|c|c|}
\hline 2. & Rusak Berat & $\begin{array}{l}\text { Bangunan masih berdiri, } \\
\text { sebagian kecil } \\
\text { komponen struktur } \\
\text { rusak, dan komponen } \\
\text { arsitektur rusak }\end{array}$ & $\begin{array}{l}\text { Bangunan masih } \\
\text { berdiri; Sebagian } \\
\text { rangka atap patah; } \\
\text { Balok kolom sebagian } \\
\text { patah; } \\
\text { Sebagian besar langit- } \\
\text { langit lepas; } \\
\text { Sebagian instalasi } \\
\text { listrik rusak/terputus; } \\
\text { dan Pintu/jendela } \\
\text { rusak } \\
\text { berat. }\end{array}$ \\
\hline 3. & $\begin{array}{l}\text { Rusak Sedang/ } \\
\text { Ringan }\end{array}$ & $\begin{array}{l}\text { Bangunan masih } \\
\text { berdiri, sebagian } \\
\text { komponen struktur } \\
\text { dan arsitektural retak } \\
\text { (struktur tidak aman } \\
\text { untuk ditinggali) }\end{array}$ & $\begin{array}{l}\text { Bangunan masih } \\
\text { berdiri; Retak-retak } \\
\text { pada dinding } \\
\text { plesteran; } \\
\text { Penutup atap/genteng } \\
\text { lepas sebagian } \\
\text { penutup langit-langit } \\
\text { rusak; Sebagian } \\
\text { instalasi rusak; } \\
\text { Instalasi listrik rusak } \\
\text { sebagian; dan } \\
\text { Pintu/jendela rusak } \\
\text { sebagian. }\end{array}$ \\
\hline
\end{tabular}

\section{Dampak Gempa Tektonik Terhadap Trauma Psikis}

Secara implikatif, gempa bumi yang terjadi itu berdampak pada kehidupan psikologis warga masyarakat dan terutama pada anak-anak yang menjadi korban. Tekanan psikologis, seperti perasaan takut berpisah, takut pada orang lain, takut pada hewan-hewan tertentu, sulit tidur, tidak ada napsu makan, perut merasa mual, ngompol, menghisap jari dan sering menangis. Hal tersebut merupakan gejala-gejala trauma pada anak.Karena pada dasarnya hakekat psikis menurut Soemadi Soerjabrataadalah pernyataan pribadi kedalam, pengarahan pribadi kedalam dirinya sendiri (Innerung).Yaitu sebuah persoalan yang dipendam dalam hati. Untuk orang tua, efek trauma bisa diperparah kelemahan tubuh yang sering menandai kehidupan manusia di usia senja, terutama kelemahan sistem saraf, serta kelemahan jantung dan sistem peredaran darah.

\section{Dampak Buruk Gempa Tektonik Bagi Kehidupan Ekonomi}

Konsep kehidupan ekonomi dapat dikatakan merupakan jawaban atas realitas ketidakberdayaan (disempowerment). Mereka yang tidak berdaya jelas adalah pihak yang tidak mempunyai daya atau kehilangan daya kekuatan. Dapat dikatakan mereka yang tidak berdaya adalah mereka yang kehilangan kekuatannya. Di dalam masyarakat terdapatnya suatu unsur nilai-nilai instrinsik yang menjadi sumber kehidupan yaitu kekeluargaan dan kegotongroyongan. Kehidupan masyarakat adalah unsur dasar yang memungkinkan suatu masyarakat bertahan dan dalam pengertian yang dinamis mengembangkan diri dan mencapai kemajuan. Adapun arti memberdayakan masyarakat adalah strategi untuk meningkatkan harkat dan martabat lapisan masyarakat, dalam kondisi sekarang tidak mampu melepaskan diri dari perangkap kemiskinan dan keterbelakangan.

Dengan kata lain memberdayakan masyarakat adalah memampukan dan memandirikan masyarakat.Pada dasarnya proses kehidupan mengandung dua kecenderungan, antara lain: pertama, proses kehidupan menekankan pada proses memberikan dan mengalihkan sebagian kekuasaan atau kekuatan dan kemampuan kepada masyarakat agar individu menjadi lebih berdaya. Proses ini dilengkapi dengan strategi membangun aset material guna mendukung pembangunan kemandirian melalui organisasi. Kecenderungan kehidupan ini disebut kecenderungan primer dari makna kehidupan. Kedua, kecenderungan kehidupan yang berkaitan dengan kekuatan dalam memberdayaan masyarakat.Sistem perekonomian juga ditandai dengan adanya lembaga yang merupakan sebuah perkumpulan dalam meningkatkan kesejahteraan. ekonomi rakyat.

Kehidupan ekonomi lebih mengarah terhadap pengembangan ekonomi, sebab dalam membangun ekonomi harus meningkatkan kemampuannya dengan cara mengembangkan dan mendinamisasikan potensinya. Mengembangkan ekonomi rakyat berarti mengembangkan sistem ekonomi rakyat, oleh rakyat dan untuk rakyat. Dengan demikian rakyat ikut berpartisipasi meningkatkan kesejahteraan. Pengembangan ekonomi rakyat menurut Gregory Grossman, dapat dilihat dari tiga sisi, yaitu : 
a. Menciptakan suasana atau iklim yang memungkinkan potensi masyarakat berkembang.

b. Memperkuat potensi ekonomi yang dimiliki oleh masyarakat itu.

c. Mengembangkan ekonomi rakyat juga mengandung arti melindungi masyarakat.

Strategi pengembangan dan pemberdayaan perekonomian rakyat, perlu diarahkan untuk mendorong terjadinya perubahan struktural. Hal ini bisa dilakukan dengan memperkuat kedudukan dan peran ekonomi rakyat dalam konstelasi perekonomian nasional. Perubahan struktural ini bisa meliputi proses perubahan dari pola tradisional ke arah ekonomi modern, dari ekonomi lemah ke ekonomi tangguh, dari ekonomi subtansi ke ekonomi pasar, dan dari ketergantungan ke arah kemandirian.

Perubahan struktural seperti ini tentu saja mensyaratkan langkah. Langkah dasar yang meliputi pengawasan sumber daya, penguatan kelembagaan, penguasaan kelembagaan serta pengembangan dan pemberdayaan sumber daya manusia.Adapun tujuan pengembangan peran masyarakat antara lain adalah sebagai berikut:

a. Meningkatkan peran masyarakat dengan berbagai unsurnya dalam Strategi meningkatkan efektivitas dan efisiensi pembangunan diri dan lingkungannya secara berkelanjutan.

b. Meningkatkan kualitas individu-individu masyarakat sebagai sumber kekuatan perannya yang akan berakses pada peningkatan kapasitas masyarakat secara umum.

c. Meningkatkan fungsi kelembagaan lokal sebagai basis partisipasi masyarakat dalam mengoptimalkan perannya dalam pembangunan

d. Meningkatkan kapasitas manajemen dan teknis kepada masyarakat dalam strategi mengoptimalkan perannya dan strategi bangkit dari keterpurukan akibat gempa bumi.

\section{METODE \\ Metode Penelitian}

Metode yang digunakan dalam penelitian ini adalah metode deskriptif, yaitu metode yang bertujuan untuk meneliti status sekelompok manusia, suatu objek, suatu kondisi, sistem pemikiran ataupun suatu kejadian peristiwa masa sekarang yang bertujuan untuk membuat deskripsi, gambaran atau lukisan secara sistematis, faktual dan aktual mengenai fakta, sifat serta hubungan antara fenomena yang diselidiki. (Nazir,2009). Data yang dikumpulkan semata-mata bersifat deskriptif sehingga tidak bermaksud mencari penjelasan, menguji hipotesi, membuat prediksi maupun mempelajari implikasi (Azwar,2007).

\section{Unit Analisis}

Unit analisis dalam penelitian ini adalah masyarakat yang terkena dampak gempa yang ada di Kecamatan Pemenang Kabupaten Lombok Utara.

\section{Penentuan Sampel}

\section{Penentuan Daerah Penelitian}

Penetuan daerah penelitian akan dilaksanakan di Kecamatan Pemenang yang terdiri dari desa Malaka, Pemenang Barat, Pemenang Timur dan Gili Indah. Penelitian ini nantinya akan dilakukan di seluruh desa dengan teknik pengambilan sampel secara Purposive Sampling dengan pertimbangan bahwa pemenang merupakan salah satu kecamatan yang memiliki prospek pariwisata yang meenjanjikan. Oleh karena itu pemenang merupakan salah satu kecamatan yang sesuai dengan tujuan penelitian untuk mengetahui perubahan sosial ekonomi yang terjadi sebelum dan setelah gempa.

\section{Penentuan Responden}

Responden adalah masyarakat kecamatan Pemenang yang terdiri dari desa Malaka, Pemenang Barat, Pemenang Timur, dan Gili Indah. Dengan populasi penduduk sebanyak 36.388 jiwa dengag uraian: Desa Malaka 8.959 jiwa, Pemenang Barat 13.742 jiwa, Pemenang Timur 7.443 jiwa, dan Gili Indah sebanya 6.244 jiwa (BPS: 2018).

Penentuan jumlah responden denagn tekhnik Quota Sampling yaitu sebanyak 182 Responden atau $0.5 \%$ dari jumlah populasi. Penentuan jumlah responden masing-masing desa sampel dilakukan dengan tekhnik 
Proportional sampling, denga rincian sebagai berikut :

$\checkmark$ Desa Malaka $=\frac{8.959 \times 182}{36.388}=45$

$\checkmark$ Desa Pemenang Barat $=\frac{13.742 \times 182}{36.388}=69$

$\checkmark$ Desa Pemenang Timur $=\frac{7.443 \times 182}{36.388}=37$

$\checkmark$ Desa Gili Indah $=\frac{6.244 \times 182}{36.388}=31$

Penentuan responden masing-masing desa dilakukan dengan Acciddental Samplingg yaitu penentuan responden secara kebetulan pada saat penelitian.

Jenis data yang digunakan dalam penelitian ini adalah data kualitatif dan kuantitatif . Data kualitatif adalah data yang tidak dapat diukur dan berupa informasi yang diperoleh dari hasil wawancara langsung dengan responden yang berpedoman pada daftar pertanyaan (kuisioner) seperti keadaan sosial masyarakat yang terdampak gempa. Sedangkan data kuantitatif merupakan data yang berupa angka dan dapat diukur seperti pendapatan, pengeluaran masyarakat.

\section{Sumber Data}

Berdasarkan jenis sumber data yang digunakan dalam penelitian ini menggunakan data primer dan data sekunder. Data primer dalam penelitian ini adalah data yang diperoleh langsung dari responden melalui wawancara dengan masyarakat yang terdampak gempa. Sedangkan data sekunder merupakan data yang diperoleh dari instansi atau kelembagaan yang terkait seperti BPS Nusa Tenggara Barat.

\section{Variabel Pengukuran}

Variabel adalah objek $\begin{gathered}\text { penelitian } \\ \text { yang }\end{gathered}$ (Arikunto,
bervariasi
2010:159).Variabel yang digunakan dalam penelitian kondisi sosial ekonomi rumah tangga pasca gempa di Kecamatan Pemenang Kabupaten Lombok Utara, terdiri dari 2 variabel sebagai berikut.

1. Kondisi sosial ekonomi rumah tangga pasca gempa variabel bebasnya adalah

kondisi sosial ekonomi rumah tangga sebelum terjadi gempa. Dengan subvariabel berupa kondisi fisik (kondisi rumah, sekitar rumah (lingkungan, pepohonan, tanaman), kondisi ternak dan perikanan, kondisi alat transportasi, kondisi alam (persawahan dan perkebunan), kondisi sosial seperti jaringan kekerabatan, kondisi ekonomi seperti mata pencaharian, kondisi secara financial, kondisi psikologis, a) kondisi sosial, sub-variabel kondisi sosial dalam penelitian ini merupakan informasi tentang aktivitas yang dilakukan secara rutin (harian) oleh penduduk terdampak gempa di Kecamatan Pemenang sebelum terjadi gempa, b) kondisi ekonomi, subvariabel kondisi ekonomi dalam penelitian ini merupakan informasi tentang mata pencaharian, kepemilikan harta benda, pendapatan dan pengeluaran penduduk terdampak gempa di Kecamatan Pemenang sebelum terjadi gempa.

2. Kondisi pasca gempa merupakan kondisi fisik, sosial, dan ekonomi rumah tangga terdampak setelah terjadi gempa.

\section{Analisis Data}

Data yang bersifat kuantitatif, diproses dengan beberapa cara antara lain (a) dijumlahkan, dibandingkan dengan jumlah yang diharapkan dan diperoleh prosentase, (b) dijumlahkan diklasifikasikan sehingga merupakan suatu susuan urut data, untuk selanjutnya dibuat table saja atau diproses lebih lanjut menjadi perhitungan kesimpulan atau visualisasi dan dengan bentuk grafik, dengan tujuan agar data ini memudahkan peneliti atau orang lain memahami hasil penelitian (Wahab, 2009:28). Analisis data ini dilakukan sebagai tindak lanjut dari menjawab pertanyaan serta tujuan penelitian yang pertama, kedua dan ketiga.Analisis ini digunakan untuk variabelvariabel dengan sebaran-sebaran frekuensi, baik dengan angka mutlak maupun dengan presentase. Indikator dari masing-masing variabel untuk analisa deskriptif diukur dengan memberikan bobot masing-masing kategori. Analisis data dalam penelitian ini dikelompokkan berdasarkan tujuan dari penelitian ini sendiri. Analisis deskriptif persentase digunakan untuk menganalisiskondisi sosial ekonomi rumah 
tangga pasca gempa di Kecamatan Pemenang Kabupaten Lombok Utara.

Analisis deskriptif digunakan untuk menganalisis bagaimana kondisi social ekonomi rumah tangga sebelum dan sesudah pasca gempa. Lokasi terdampak gempa dianalisis menggunakan analisis keruangan. Pengertian dari analisis-analisis diatas dapat didefinisikan sebagai berikut:

1) Deskripsi persentase digunakan untuk menampilkan data-data kuantitatif ke dalam kalimat, 2) analisis deskriptif berfungsi untuk memberikan gambaran umum tentang data yang telah diperoleh, gambaran umum ini bisa menjadi acuan untuk melihat karakteristik data yang telah diperoleh, 3) analisis keruangan merupakan suatu metode dalam memahami dan menilai keadaan yang didasarkan pada informasi yang mencakup lokasi atau tempat.

Analisis deskriptif persentase memiliki rangkaian langkah dalam menganalisis suatu data. Sebelum data dihitung dengan rumus deskriptif persentase, maka terlebih dahulu menghitung skor jawaban tes dari masingmasing responden dengan memberikan tingkat skor untuk masing-masing jawaban. Berikut ini adalah analisis variabel pengetahuan, penilaian, dan kondisi sosial ekonomi rumah tangga pasca gempa.

\section{Skoring}

Skoring yaitu memberikan skor pada setiap soal. Pada tahap ini pemberian skor akan mempermudah peneliti dalam melakukan penilaian. Adapun kriteria pemberian skor mengenai aspek pengetahuan kondisi sosial ekonomi rumah tangga pasca gempa adalah adalah sebagai berikut. Untuk pertanyaan kondisi pasca gempa (kondisi fisik, kondisi sosial, kondisi ekonomi, kondisi financial, kondisi psikologis) dalam pengukuran data, peneliti menggunakan system kategori yang dibuat oleh Rensis Likert, penilaian kuesioner yang digunakan adalah berdasarkan skala Likert. Pemberian bobot dilakukan dengan ketentuan sebagai berikut : untuk jawaban
(a) diberi bobot
4, jawaban
(b) diberi

bobot 3, jawaban (c) diberi bobot 2, Jawaban (d) diberi bobot 1. Sedang kan untuk poin pertanyan pendapat responden Rensis Likert, penilaian kuesioner yang digunakan adalah berdasarkan skala Likert. Pemberian bobot dilakukan dengan ketentuan, jawabansangat setuju diberi bobot 5, jawaban setuju diberi bobot 4, jawaban ragu-ragu diberi bobot 3 , jawaban kurang setuju diberi bobot 2, jawaban tidak setuju diberibobot 1 .

\section{Menentukan Parameter}

Penentuan parameter di dalam penelitian kondisi sosial ekonomi rumah tangga pasca gempa di Kecamatan Pemenang Kabupaten Lombok Utara berupa kondisi sosialekonomi rumah tangga pasca gempa di Kecamatan Pemenang Kabupaten Lombok Utara.

Berikut adalah langkah-langkah dalam menentukan parameter.

a. Menentukan skor maksimal $=$ jumlah soal $\mathrm{x}$ skor maksimal

b. Menentukan skor minimal $=$ jumlah soal $\mathrm{x}$ skor minimal

c. Menghitung rentang nilai $=$ skor maksimal - skor minimal

d. Menentukan kriteria

Penentuan kriteria dalam penelitian kondisi sosial ekonomi rumah tangga pasca gempa di Kecamatan Pemenang Kabupaten Lombok Utara dapat disesuaikan dengan kebutuhan kelas yang akan dibuat. Penduduk terdampak menurut KK penentuan kriteria kelas dibagi menjadi 3, yaitu tinggi, sedang, dan rendah.

e. Menghitung interval kelas

\section{Parameter}

$$
=\frac{\text { Rentang }}{\text { Banyak Kriteria }}
$$

Menyusun parameter luas wilayah, penduduk terdampak banjir menurut $\mathrm{kk}$ terdampak gempa baik permukiman dan pertanian didasarkan atas kriteria yang sudah ditentukan. Dari masing-masing tujuan tersebut mengikuti jalur sesuai dengan kelas yang telah ditentukan oleh interval kelas.

Membuat tabel frekuensi variabel kondisi sosial ekonomi rumah tangga pasca 
gempa di Kecamatan Pemenang Kabupaten Lombok Utara. Tabel frekuensi dibuat untuk mempermudah dalam menghitung jumlah frekuensi berdasarkan nilai yang diperoleh petani dalam penelitian. Dan untuk mengetahui analisis frekuensi menggunakan teknik DP (Deskriptif Persentase) dengan menggunakan rumus sebagai berikut.

Keterangan :

$$
\mathrm{P}=\mathrm{x} 100 \%
$$

$$
\begin{aligned}
& \mathrm{P}=\text { angka persentase } \\
& \mathrm{F}=\text { frekuensi yang sedang dicari } \\
& \text { persentasenya } \\
& \mathrm{N}=\text { jumlah frekuensi banyaknya } \\
& \text { individu }
\end{aligned}
$$

\section{HASIL PENELITIAN DAN PEMBAHASAN \\ Lokasi Penelitian}

Dilaksanakan di Kecamatan Pemenang Kabupaten Lombok Utara. Kecamatan Pemenang memiliki keunggulan di bidang pariwisata. Secara geografis Kecamatan Pemenang memiliki batasan wilayah dengan :

1. Sebelah utara : Laut Jawa

2. Sebelah barat : Selat Lombok

3. Sebelah timur : Kecamatan Tanjung

4. Sebelah Selatan : Kabupaten Lombok Barat

Kecamatan Pemenang mencakup 4 desa yaitu:

1. Desa Malaka

$: 12,41 \mathrm{Km}^{2}$

2. Desa Pemenang Barat $: 83,69 \mathrm{Km}^{2}$

3. Desa Pemenang Timur $: 26,66 \mathrm{Km}^{2}$

4. Desa Gili Indah : $6,78 \mathrm{Km}^{2}$

Pembagian wilayah administrasi

Kecamatan Pemenang dirinci menurut dusun, dan RT yang ada disetiap wilayah desa pada tahun 2016 dapat dilihat pada tabel berikut ini:

Table 2

\begin{tabular}{|c|l|c|c|}
\hline No & \multicolumn{1}{|c|}{ Desa } & $\begin{array}{c}\text { Jumlah } \\
\text { Dusun }\end{array}$ & $\begin{array}{c}\text { Jumlah } \\
\text { RT }\end{array}$ \\
\hline 1 & Desa Malaka & 12 & 36 \\
\hline 2 & Desa Pemenang Barat & 10 & 68 \\
\hline 3 & Desa Pemenang Timur & 13 & - \\
\hline 4 & Desa Gili Indah & 2 & 17 \\
\hline \multicolumn{2}{|r|}{ Jumlah } & 38 & 121 \\
\hline
\end{tabular}

Karakteristik Responden
Responden adalah masyarakat terdampak bencana gempa bumi di Kecamatan Pemenang Kabupaten Lombok Utara yaitu desa Malaka, desa Pemenang Barat, desa Pemenang Timur, dan desa Gili Indah.

Data secara umum, struktur penduduk Kabupaten Lombok Utara pada tahun 2017 didominasi oleh penduduk dengan jenis kelamin perempuan.

Responden sebagian besar berumur 26 - 45 tahun sebanyak 96 orang $(52,7 \%)$. Hal ini menunjukkan bahwa dari segi umur penduduk Kecamatan Pemenang berada pada usia produktif.

Penduduk tamat SD sebanyak 64 orang $(35,2 \%)$. Tidak sekolah sebanyak 31 orang $(17,0 \%)$. Tidak tamat SD sebanyak 18 orang $(9,9 \%)$. Kondisi ini menunjukkan bahwa target pendidikan wajib belajar 9 tahun masih belum tercapai.

Pekerjaan utama responden adalah wiraswasta sebanyak 69 orang $(37,9 \%)$ dan buruh/tukang bangunan sebanyak 53 orang $(29,1 \%)$.

Wajib belajar 9 tahun responden masih belum tercapai. Hal ini dapat dipahami jika dilihat dari tingkat pendidikan responden yang sebagian besar tidak sekolah dan tidak tamat.

Tingkat pendidikan ini akan berdampak pada profesi pekerjaan yang sebagian besar mempersyaratkan tingkat pendidikan tertentu. Sebagian besar responden menyatakan tidak memiliki pekerjaan sampingan yaitu sebanyak 160 orang $(87,9 \%)$. Hal ini bisa dipahami dikarenakan kondisi perekenomian di Kecamatan Pemenang masih terdampak bencana gempa bumi.

Tabel 3. Distribusi Frekuensi Karakteristik Responden

\begin{tabular}{|l|l|c|c|}
\hline \multicolumn{2}{|c|}{ Karakteristik Responden } & Jumlah & $\begin{array}{c}\text { Presentase } \\
(\%)\end{array}$ \\
\hline Jenis Kelamin & Laki-laki & 43 & 23,6 \\
& Perempuan & 139 & 76,4 \\
\hline Umur: & $17-25$ tahun & 27 & 14,8 \\
& $26-45$ tahun & 96 & 52,7 \\
& $46-65$ tahun & 52 & 28,6 \\
& $>65$ tahun & 7 & 3,8 \\
\hline Pendidikan & Tidak Pernah & 31 & 17 \\
Responden & Sekolah & 18 & 9,9 \\
& Tidak Tamat SD & 64 & 35,2 \\
\hline
\end{tabular}


Jurnal Ilmiah Mandala Education

http://ejournal.mandalanursa.org/index.php/JIME/index

Terakreditasi Peringkat 4 (No. SK: 36/E/KPT/2019)

\begin{tabular}{|c|c|c|c|}
\hline & $\begin{array}{l}\text { Tamat SD } \\
\text { SLTP } \\
\text { SLTA } \\
\text { Lainnya }\end{array}$ & $\begin{array}{c}25 \\
36 \\
8\end{array}$ & $\begin{array}{c}13,7 \\
19,8 \\
4,4\end{array}$ \\
\hline $\begin{array}{l}\text { Pekerjaan } \\
\text { utama } \\
\text { responden }\end{array}$ & $\begin{array}{l}\text { Wiraswasta } \\
\text { PNS } \\
\text { Karyawan } \\
\text { swasta } \\
\text { petani/ternak } \\
\text { nelayan } \\
\text { Buruh/Tukang } \\
\text { Bangunan } \\
\text { Tidak } \\
\text { bekerja/tidak } \\
\text { ada }\end{array}$ & $\begin{array}{c}69 \\
1 \\
15 \\
5 \\
7 \\
53 \\
32\end{array}$ & $\begin{array}{c}37,9 \\
0,5 \\
8,2 \\
2,7 \\
3,8 \\
29,1 \\
17,6\end{array}$ \\
\hline $\begin{array}{l}\text { Pekerjaan } \\
\text { sampingan }\end{array}$ & $\begin{array}{l}\text { Wiraswasta } \\
\text { PNS } \\
\text { Karyawan } \\
\text { swasta } \\
\text { petani/ternak } \\
\text { nelayan } \\
\text { Buruh/Tukang } \\
\text { Bangunan } \\
\text { Tidak } \\
\text { bekerja/tidak } \\
\text { ada }\end{array}$ & $\begin{array}{c}12 \\
- \\
- \\
5 \\
1 \\
4 \\
160\end{array}$ & $\begin{array}{c}6,4 \\
- \\
- \\
2,7 \\
0,5 \\
2,2 \\
87,9\end{array}$ \\
\hline
\end{tabular}

\section{Kondisi Sosial Ekonomi}

\section{Kondisi Sosial}

\begin{tabular}{|c|c|c|c|c|c|}
\hline \multirow{2}{*}{\multicolumn{2}{|c|}{ Kondisi }} & \multicolumn{2}{|c|}{ Sebelum } & \multicolumn{2}{|c|}{ Sesudah } \\
\hline & & Frekuensi & Persentase & Frekuensi & Persentase \\
\hline \multirow{3}{*}{$\begin{array}{l}\text { Aktivitas } \\
\text { sosial }\end{array}$} & Sering & 136 & 74,7 & 134 & 73,6 \\
\hline & Kadang & 27 & 14,8 & 28 & 15,4 \\
\hline & Tidak Pernah & 19 & 10,4 & 20 & 11,0 \\
\hline \multirow[t]{3}{*}{ Interaksi } & Sering & 126 & 69,2 & 123 & 67,6 \\
\hline & Kadang & 54 & 29,7 & 54 & 29,7 \\
\hline & Tidak Pernah & 2 & 1,1 & 5 & 2,7 \\
\hline \multirow{3}{*}{$\begin{array}{l}\text { Program } \\
\text { Pemberd } \\
\text { ayaan } \\
\text { Pemerint } \\
\text { ah }\end{array}$} & Sering & 32 & 17,6 & 30 & 16,5 \\
\hline & Kadang & 68 & 37,4 & 68 & 37,4 \\
\hline & Tidak Pernah & 82 & 45,1 & 84 & 46,2 \\
\hline \multirow{3}{*}{$\begin{array}{l}\text { Gotong } \\
\text { Royong }\end{array}$} & Sering & 145 & 79,7 & 139 & 76,4 \\
\hline & Kadang & 21 & 11,5 & 19 & 10,4 \\
\hline & Tidak Pernah & 16 & 8,8 & 24 & 13,2 \\
\hline \multirow{3}{*}{$\begin{array}{l}\text { Kegiatan } \\
\text { Kebuday } \\
\text { aan }\end{array}$} & Sering & 47 & 25,8 & 42 & 23,1 \\
\hline & Kadang & 125 & 68,7 & 130 & 71,4 \\
\hline & Tidak Pernah & 10 & 5,5 & 10 & 5,5 \\
\hline \multirow{3}{*}{ Hajatan } & Sering & 54 & 29,7 & 57 & 31,3 \\
\hline & Kadang & 122 & 67,0 & 119 & 65,4 \\
\hline & Tidak Pernah & 6 & 3,3 & 6 & 3,3 \\
\hline \multirow{3}{*}{$\begin{array}{l}\text { Pengajia } \\
n\end{array}$} & Sering & 121 & 66,5 & 115 & 63,2 \\
\hline & Kadang & 34 & 18,7 & 34 & 18,7 \\
\hline & Tidak Pernah & 27 & 14,8 & 33 & 18,1 \\
\hline \multirow[t]{3}{*}{ Arisan } & Sering & 49 & 26,9 & 34 & 18,7 \\
\hline & Kadang & 9 & 4,9 & 8 & 4,4 \\
\hline & Tidak Pernah & 124 & 68,1 & 140 & 76,9 \\
\hline \multirow{3}{*}{$\begin{array}{l}\text { Posyand } \\
\mathrm{u}\end{array}$} & Sering & 72 & 39,6 & 76 & 41,8 \\
\hline & Kadang & 9 & 4,9 & 12 & 6,6 \\
\hline & Tidak Pernah & 101 & 55,5 & 94 & 51,6 \\
\hline
\end{tabular}

\section{Kondisi Rumah}

\begin{tabular}{|l|l|l|l|l|l|}
\hline \multicolumn{2}{|c|}{ Kondisi rumah } & \multicolumn{2}{c|}{ Sebelum } & \multicolumn{2}{c|}{ Sesudah } \\
\cline { 2 - 6 } & Frekuensi & Persentase & Frekuensi & Persentase \\
\hline \multirow{4}{*}{ Dinding } & Tembok & 170 & 93,4 & 41 & 22,5 \\
\cline { 2 - 6 } & Klasibot & & & 32 & 17,6 \\
\cline { 2 - 6 } & Bedek/triplek & 12 & 6,6 & 37 & 20,3 \\
\cline { 2 - 6 } & Rusak & & & 72 & 39,6 \\
\hline \multirow{4}{*}{ Atap } & Genteng & 46 & 25,3 & 13 & 7,1 \\
\cline { 2 - 6 } & Asbes & 92 & 50,5 & 22 & 12,1 \\
\cline { 2 - 6 } & Spandek & 31 & 17,0 & 63 & 34,6 \\
\cline { 2 - 6 } & Seng & 11 & 6,0 & 13 & 7,1 \\
\cline { 2 - 6 } & Alang-alang & 2 & 1,1 & 3 & 1,6 \\
\cline { 2 - 6 } & Daun Kelapa & 2 & & 68 & 37,4 \\
\cline { 2 - 6 } & Rusak & & 62,1 & 41 & 22,5 \\
\hline Lantai & Keramik & 113 & 1,8 & 61 & 33,5 \\
\cline { 2 - 6 } & Semen & 67 & & & 23,1 \\
\cline { 2 - 6 } & Kayu & 2 & & & \\
\hline
\end{tabular}

Vol. 7. No. 3 Agustus 2021 p-ISSN: 2442-9511 e-ISSN: 2656-5862

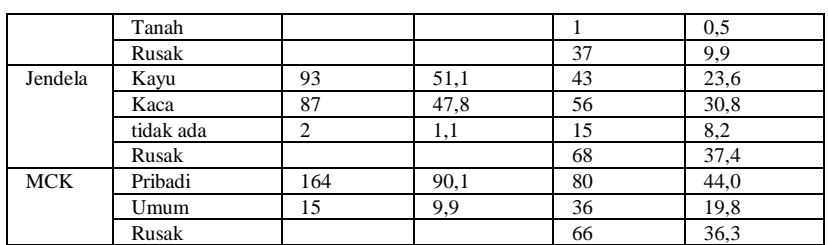

Kondisi Pekarangan dan Tanaman

\begin{tabular}{|l|l|l|l|l|l|}
\hline \multicolumn{2}{|c|}{ Kondisi } & \multicolumn{2}{c|}{ Sebelum } & \multicolumn{2}{c|}{ Sesudah } \\
\cline { 2 - 6 } & Frekuensi & Persentase & Frekuensi & Persentase \\
\hline Pekarangan & Ada & 99 & 54,4 & 92 & 50,5 \\
\cline { 2 - 6 } & $\begin{array}{l}\text { Tidak } \\
\text { ada }\end{array}$ & 83 & 45,6 & 90 & 49,5 \\
\hline Tanaman & Ada & 80 & 44,0 & 74 & 40,7 \\
\cline { 2 - 6 } & $\begin{array}{l}\text { Tidak } \\
\text { ada }\end{array}$ & 102 & 56,0 & 108 & 59,3 \\
\hline
\end{tabular}

\section{Pekerjaan Pasangan}

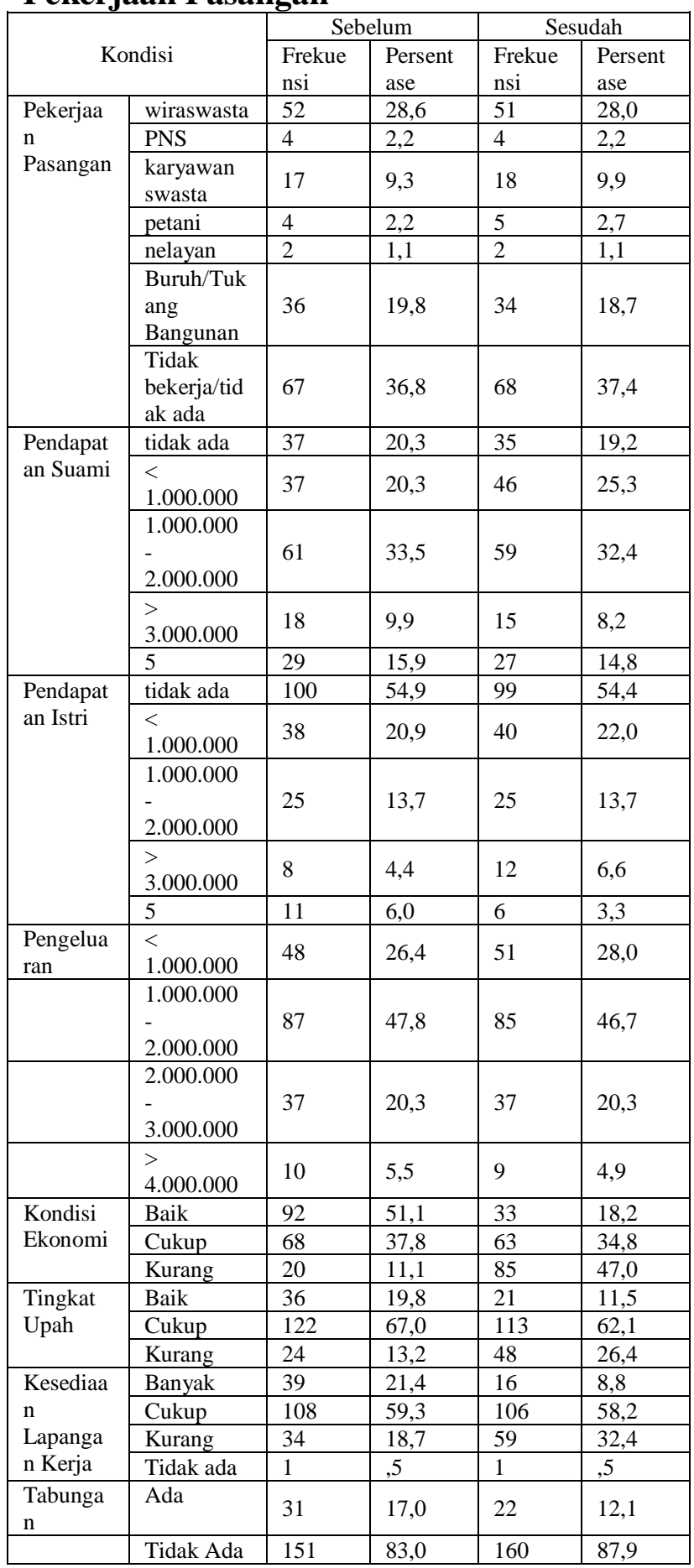




\begin{tabular}{|c|c|c|c|c|c|}
\hline \multirow[t]{2}{*}{ Motor } & Ada & 104 & 57,5 & 99 & 54,4 \\
\hline & Tidak Ada & 77 & 42,5 & 83 & 45,6 \\
\hline \multirow[t]{2}{*}{ Mobil } & Ada & 9 & 4,9 & 9 & 4,9 \\
\hline & Tidak Ada & 173 & 95,1 & 173 & 95,1 \\
\hline \multirow[t]{2}{*}{ TV } & Ada & 124 & 68,5 & 102 & 56,0 \\
\hline & Tidak Ada & 57 & 31,5 & 80 & 44,0 \\
\hline \multirow[t]{2}{*}{ Kulkas } & Ada & 91 & 50,0 & 80 & 44,0 \\
\hline & Tidak Ada & 91 & 50,0 & 102 & 56,0 \\
\hline \multirow[t]{2}{*}{ HP } & Ada & 108 & 59,3 & 102 & 56,0 \\
\hline & Tidak Ada & 74 & 40,7 & 80 & 44,0 \\
\hline \multirow[t]{2}{*}{ Laptop } & Ada & 20 & 11,0 & 19 & 10,4 \\
\hline & Tidak Ada & 162 & 89,0 & 163 & 89,6 \\
\hline \multirow{2}{*}{$\begin{array}{l}\text { Mesin } \\
\text { Cuci }\end{array}$} & Ada & 71 & 39,0 & 69 & 38,1 \\
\hline & Tidak Ada & 111 & 61,0 & 112 & 61,9 \\
\hline \multirow{3}{*}{$\begin{array}{l}\text { Pendingi } \\
\mathrm{n} \\
\text { Ruangan }\end{array}$} & $\mathrm{AC}$ & 90 & 49,5 & 79 & 43,4 \\
\hline & $\begin{array}{l}\text { Kipas } \\
\text { angin }\end{array}$ & 90 & 49,5 & & \\
\hline & Tidakada & 2 & 1,1 & 103 & 56,6 \\
\hline \multirow{2}{*}{$\begin{array}{l}\text { Perabot } \\
\text { Rumah } \\
\text { Tangga }\end{array}$} & Ada & 89 & 48,9 & 70 & 38,5 \\
\hline & Tidak Ada & 93 & 51,1 & 112 & 61,5 \\
\hline \multirow[t]{2}{*}{ Unggas } & Ada & 76 & 41,8 & 76 & 41,8 \\
\hline & Tidak Ada & 106 & 58,2 & 106 & 58,2 \\
\hline \multirow[t]{2}{*}{ Ikan } & Ada & 4 & 2,2 & 2 & 1,1 \\
\hline & Tidak Ada & 178 & 97,8 & 180 & 98,9 \\
\hline \multirow[t]{2}{*}{ Kambing } & Ada & 4 & 2,2 & 4 & 2,2 \\
\hline & Tidak Ada & 178 & 97,8 & 178 & 97,8 \\
\hline \multirow[t]{2}{*}{ Sapi } & Ada & 15 & 8,2 & 15 & 8,2 \\
\hline & Tidak Ada & 167 & 91,8 & 167 & 91,8 \\
\hline \multirow[t]{2}{*}{ Sawah } & Ada & 10 & 5,5 & 8 & 4,4 \\
\hline & Tidak Ada & 172 & 94,5 & 174 & 95,6 \\
\hline \multirow[t]{2}{*}{ Kebun } & Ada & 14 & 7,7 & 14 & 7,7 \\
\hline & Tidak Ada & 168 & 92,3 & 168 & 92,3 \\
\hline \multirow{2}{*}{$\begin{array}{l}\text { Perhiasa } \\
\mathrm{n}\end{array}$} & Ada & 53 & 29,1 & 50 & 27,5 \\
\hline & Tidak Ada & 129 & 70,9 & 132 & 72,5 \\
\hline \multirow[t]{2}{*}{ Saham } & Ada & & & & \\
\hline & Tidak Ada & 182 & 100,0 & 182 & 100,0 \\
\hline
\end{tabular}

berhubungan dengan tingkat pendidikan masyarakat yang masih rendah.

\section{DAFTAR PUSTAKA}

Anonim 2018. (https://id.wikipedia.org/wiki/Bencana _alam). Diakses pada tanggal 12 november 2018

Dinas Komunikasi dan Informatika. 2017. Kabupaten Lombok Utara dalam Data.

Listya, 2011 "Dampak Ekonomi Makro Bencana : Interaksi Bencana Dan Pembangunan Ekonomi Nasional" dalam "Zapata-Marti, R.,(1997), Methodological approaches: the ECLAC methodology. In Center for the Research on the Epidemiology of Disasters (CRED), Assessment of the economic impact of natural and man-made disasters. Proceedings of the expert consultation on methodologies, Brussels, 29-30 September, Universite Catholique de Louvain, Belgium, 10-12.'

Listya, 2011 "Dampak Ekonomi Makro Bencana : Interaksi Bencana Dan Pembangunan Ekonomi Nasional" dalam "Benson, C.,(1997), The economic impact of natural disasters in the Philippines. Working paper 99. London: Overseas Development Institute."

\section{Dampak Gempa}

\begin{tabular}{|l|r|r|r|r|r}
\hline \multicolumn{1}{|c|}{ Dampak } & Sangat Setuju & \multicolumn{1}{c|}{ Setuju } & \multicolumn{1}{c|}{ Ragu-ragu } & Tidak Setuju & \multicolumn{1}{c}{$\begin{array}{c}\text { Sangat Tidak } \\
\text { Setuju }\end{array}$} \\
\hline Gempa berdampak negatif & $54(29,7 \%)$ & $81(44,5 \%)$ & $12(6,6 \%)$ & $34(18,7 \%)$ & $1(0,5 \%)$ \\
\hline $\begin{array}{l}\text { Gempa mengganggu kegiatan } \\
\text { sosial }\end{array}$ & $47(25,8 \%)$ & $87(47,8 \%)$ & $5(2,7 \%)$ & $37(20,3)$ & $6(3,3 \%)$ \\
\hline $\begin{array}{l}\text { Gpema menyebabkan gangguan } \\
\text { psikologis }\end{array}$ & $67(36,8 \%)$ & $108(59,3 \%)$ & $3(1,6 \%)$ & $2(1,1 \%)$ & $2(1,1 \%)$ \\
\hline $\begin{array}{l}\text { Gempa menimbulkan kerusakan } \\
\text { dan korban }\end{array}$ & $60(33 \%)$ & $\begin{array}{l}110 \\
(60,4 \%)\end{array}$ & $3(1,6 \%)$ & $5(2,7 \%)$ & $4(2,2 \%)$ \\
\hline Perlu dilakukan pelatihan mitigasi & $107(55,8 \%)$ & $\begin{array}{c}70 \\
(38,5 \%)\end{array}$ & $3(1,6 \%)$ & & $2(1,1 \%)$ \\
\hline
\end{tabular}

Listya, 2011 "Dampak Ekonomi Makro Bencana : Interaksi Bencana Dan Pembangunan Ekonomi Nasional" dalam"Noy,Ilan (2007), The Macroeconomic Concequences of Disasters, SCCIE Working Paper 07$15 "$

\section{SIMPULAN}

1. Penduduk Kecamatan Pemenang wajib belajar 9 tahun belum tercapai.

2. Tingkat pendidikan yang masih rendah berdampak pada profesi pekerjaan.

3. Gempa bumi meninggalkan dampak buruk pada kehidupan masyarakat disegala bidang, dampak tersebut baru bisa normal kembali membutuhkan waktu yang lama, karena secara tidak langsung 